\title{
Respiratory infections, exacerbations and the microbiome in COPD
}

Citation for published version (APA):

Braeken, D. C. W. (2018). Respiratory infections, exacerbations and the microbiome in COPD. [Doctoral Thesis, Maastricht University]. Datawyse / Universitaire Pers Maastricht.

https://doi.org/10.26481/dis.20180518db

Document status and date:

Published: 01/01/2018

DOI:

$10.26481 /$ dis.20180518db

Document Version:

Publisher's PDF, also known as Version of record

\section{Please check the document version of this publication:}

- A submitted manuscript is the version of the article upon submission and before peer-review. There can be important differences between the submitted version and the official published version of record.

People interested in the research are advised to contact the author for the final version of the publication, or visit the DOI to the publisher's website.

- The final author version and the galley proof are versions of the publication after peer review.

- The final published version features the final layout of the paper including the volume, issue and page numbers.

Link to publication

\footnotetext{
General rights rights.

- You may freely distribute the URL identifying the publication in the public portal. please follow below link for the End User Agreement:

www.umlib.nl/taverne-license

Take down policy

If you believe that this document breaches copyright please contact us at:

repository@maastrichtuniversity.nl

providing details and we will investigate your claim.
}

Copyright and moral rights for the publications made accessible in the public portal are retained by the authors and/or other copyright owners and it is a condition of accessing publications that users recognise and abide by the legal requirements associated with these

- Users may download and print one copy of any publication from the public portal for the purpose of private study or research.

- You may not further distribute the material or use it for any profit-making activity or commercial gain

If the publication is distributed under the terms of Article $25 \mathrm{fa}$ of the Dutch Copyright Act, indicated by the "Taverne" license above, 
Summary 



\section{SUMMARY}

Chronic Obstructive Pulmonary Disease (COPD), characterised by persistent respiratory symptoms and airflow limitation, is one of the leading causes of death worldwide with a high economic and societal burden. COPD is a very heterogeneous disease, which makes the management complex. The disease is featured by acute events, impacting on health related quality of life, exercise capacity and activities of daily living. These acute events can be discriminated in respiratory infections, including community acquired pneumonia (CAP), and exacerbations (AECOPD). Although both disease conditions present with comparable symptoms, discrimination is important for prevention strategies, treatment options and outcomes. Therefore the current thesis aimed to better understand both disease conditions as well as to provide recommendations for which specimens to use for respiratory microbiome analysis (Chapter 1 ).

To optimise disease management, it is important to gain insight into both disease conditions. Chapter 2 and 3 aimed to assess the prevalence of COPD in CAP patients, as well as to determine characteristics and the bacterial aetiology of patients with COPD compared to non-COPD patients. A large observational study revealed that CAP patients with COPD were significantly older, more often current or former smokers, with more severe CAP, compared to non-COPD patients with CAP. Different bacterial pathogens were observed in patients with and patients without COPD, which advocates the use of different treatment options. Besides, worse outcomes were observed in patients with COPD; higher mortality rates and longer length of hospital stay. Older age and admission to an intensive care unit were observed to be related to short- and long-term mortality for patients with CAP, independent of COPD. Bacterial pathogen detection seemed to be important, as patients without pathogen detection had more severe CAP and higher mortality rates. Overall, these chapters suggest that insight into characteristics of patients with COPD and the aetiology underlying CAP might contribute to better management and treatment of patients.

Since smoking is the most important risk factor to develop COPD, and is also related to an increased risk of developing CAP, chapter 4 studied the impact of smoking on the risk to develop CAP in patients with COPD compared to patients without COPD. This study showed that current smoking is not related to an increased risk to develop CAP in patients with COPD, while this is the case in patients without COPD. Interestingly, current smoking patients with COPD had a comparable risk to develop CAP as never smoking patients with COPD. Which mechanisms underlie this observation is currently unknown and needs further investigation.

One of the main symptoms related to COPD is sputum production. This symptom is also part of the definition of AECOPD, and frequently reported by patients. In chapter 5 the influence of sputum production and sputum aetiology on patient characteristics, health status and 
exercise capacity was assessed in a population of patients with stable COPD who were referred for pulmonary rehabilitation (PR). Almost one-third of the patients with stable COPD produced a spontaneous sputum sample, with a positive culture related to a worse health status compared to patients who did not produce spontaneous sputum. Besides, patients with a positive sputum culture had a higher exacerbation frequency before PR and reported more often symptoms of chronic bronchitis. This study makes us aware of specific clinical profiles of patients with COPD, which is important in order to develop specific recommendations following the general management of patients with COPD.

Next to CAP, patients with COPD are susceptible to acute exacerbations of the disease. AECOPD are often subject of research, but still much remains unclear due to the heterogenic character of this event. In chapter 6 the impact of AECOPD, stratified by severity, on pulmonary rehabilitation (PR) was determined. This research observed that even though patients were having a mild-to-moderate AECOPD during PR, positive results were achieved at the end of PR. Unfortunately, patients with severe AECOPD during PR had on average no improvement of health related quality of life, symptoms of anxiety and depression and exercise capacity. However, these results also showed no overall decline in outcomes, which might be considered as a benefit. This should however, be investigated by comparing a group of patients with severe AECOPD during PR who finished PR, with a comparable group who did not finish PR. Still, it is important to motivate and encourage patients to complete PR even though exacerbating, as the benefits of PR have been convincingly demonstrated in the past.

Overall, the before mentioned results highlight the fact that a lot more research is necessary in the field of respiratory infections and exacerbations in patients with COPD. In the last few years, respiratory microbiome analysis is positioned as a promising technique to overcome pressing questions. Chapter 7 aims to provide a recommendation on which respiratory specimens to use for respiratory microbiome analysis in patients with COPD. Different respiratory specimens were assessed, of both the upper and lower respiratory tract. In general, the alpha and beta diversity differed between the respiratory specimens, but the patient-specific signature in the respiratory specimens was more pronounced than the specimen-specific signature. So, different respiratory specimens of one subject are more alike to each other than similar respiratory specimens of other subjects. This observation makes respiratory microbiome research in the future easier, as less invasive sampling techniques might be sufficient enough for clinical practice.

In conclusion, this thesis discussed various concepts of respiratory infections, exacerbations and the respiratory microbiome in patients with COPD (Chapter 8). Many steps are needed to understand the different disease conditions and to optimize treatment and overall management. Respiratory microbiome analysis is challenging, as well as promising to understand the development of COPD. Possibly non-invasive sampling techniques can be used to assess the respiratory microbiome for clinical practice. 